\title{
The Concept of Grammatical Organon in the Star of Redemption by Rosenzweig
}

\author{
Ilya Dvorkin
}

check for

updates

Citation: Dvorkin, Ilya. 2021. The Concept of Grammatical Organon in the Star of Redemption by Rosenzweig. Religions 12: 945. https://doi.org/ $10.3390 /$ rel12110945

Academic Editor: Cyril S. Aslanov

Received: 31 August 2021

Accepted: 13 October 2021

Published: 29 October 202

Publisher's Note: MDPI stays neutral with regard to jurisdictional claims in published maps and institutional affiliations.

Copyright: (C) 2021 by the author. Licensee MDPI, Basel, Switzerland. This article is an open access article distributed under the terms and conditions of the Creative Commons Attribution (CC BY) license (https:/ / creativecommons.org/licenses/by/ $4.0 /)$.
International Center for University Teaching of Jewish Civilization, Hebrew University of Jerusalem, Jerusalem 91905, Israel; idvorkin@mail.ru

\begin{abstract}
In his book The Star of Redemption, F. Rosenzweig formulated a new philosophical system, which is based not on thinking, or being, but on language. At the same time, Rosenzweig not only postulates language but deduces it as a procedural reality that is currently unfolding in relation to perfect and closed elements- the world, God and man. Language fundamentally changes our attitude not only toward the world, God and man but in general toward all objects of knowledge and action. The world ceases to be perceived as an equal given, a person ceases to be a generic definition for subjectivity and acquires singularity and uniqueness. God is not defined as the Absolute Reality but becomes a live interlocutor. One of the central points of Rosenzweig's system is its grammatical organon-a method that allows one to consider linguistic processes. Rosenzweig unfolds his organon in three books of the second part of The Star of Redemption. This article discusses the philosophical foundations of Rosenzweig's grammatical organon and the features of its application to various linguistic and speech phenomena.
\end{abstract}

Keywords: language; speech thinking; grammatical organon; origin word; root word; root sentence; Gestalt; pronoun; predicative; philosophy of dialogue

\section{Rosenzweig's Grammatical Organon and the Language Turn of the 20th Century}

For almost two and a half thousand years, the main theme of philosophy was the relationship between thinking and being, and language was considered, at best, as a special tool for expressing thought. Finally, at the beginning of the 20th century, a number of authors belonging to different philosophical schools started talking about the primacy of language ${ }^{1}$.

Rosenzweig occupies a special place in this turn towards language ${ }^{2}$. In 1921, Rosenzweig's fundamental book The Star of Redemption was published (Rosenzweig 1921). In it he tried to formulate his philosophical system. In his article "New Thinking" (1925), Rosenzweig characterized this system with Schelling's term "narrative philosophy" (Rosenzweig 2000, p. 121), but modern researchers use more precise expressions such as "speaking philosophy" and "speaking thinking"3 ${ }^{3}$. Rosenzweig did not just focus on the problems of language of some chapters of a book or an article, he formulated a new philosophical system, which, in his opinion, replaces the entire philosophy focused on the relationship of thinking and being "philosophy from Parmenides to Hegel" ${ }^{4}$. This new philosophy should be based not on the reflection of thinking but on language and speech. In his book, Rosenzweig not only speaks about language but formulates a special "grammatical organon", which in his philosophy should play the same role as the "mathematical organon" in the science of the New Time.

The idea of organon goes back to the first publisher of Aristotle's works, Andronicus of Rhodes. Until the 17th century, there was only one philosophical organon-that is, the logic of Aristotle, although there were very different opinions about which particular branches were included in this logic and how to understand it. However, in the 17th century, F. Bacon creates a "new organon", which formulates methods of cognition based on experiment 
and induction and not only on apodictic logical inference. The problem of the relationship between the experimental method and mathematics is a central theme in the science of the New Time; it also becomes the most important problem of Kant's philosophy with its organon of pure reason ${ }^{5}$. Kant and neo-Kantians considered mathematics to be the purest expression of the transcendental method of cognition. Therefore, following in the footsteps of $\mathrm{H}$. Cohen, Rosenzweig declares mathematics to be the organon of thinking (Rosenzweig 2005, p. 27). At the same time, such contemporaries of Kant as Hamann and Herder, in contrast to Kant, consider language to be the main organon of reason (Berlin 1993, pp. 72-92). Rosenzweig unites both positions: he speaks of the mathematical organon, the grammatical organon, and adds the liturgical organon to them ${ }^{6}$. Thus, mathematics, grammar, and liturgy become the three organons of Rosenzweig's new thinking. Each of the three parts of his book describes one of these organons:

"For this third Part, therefore, liturgy will assume a similar rank as a system of logic, that is to say an organon of mathematics in the first Part, of grammar for the second". (Rosenzweig 2005, p. 312)

The conception of Rosenzweig is formed through intense, meaningful dialogue with his friends Eugen Rosenstock-Huessy, Rudolf and Hans Ehrenberg. Since the work on The Star of Redemption was recorded in detail by the author in his correspondence with Margrit Rosenstock-Huessy (Briefe 2002, pp. 124-67), we can observe step by step how the language thinking of Rosenzweig is being formed (Meir 2005). At the same time, as he himself emphasizes (Rosenzweig 2000, p. 127), the main source of his conception is the grammatical concept of Eugen Rosenstock-Huessy. The connection of the grammatical organon of Rosenzweig, with the ideas of "Practical Knowledge of the Soul" (Rosenstock-Huessy 1988), was considered by almost all researchers of Rosenzweig's philosophy, beginning with Freund (Freund 1979, p. 152; Brasser 2004; Bienenstock 2018, p. 135). The grammatical approach permeates almost all the works of Rosenstock-Huessy, who, in "Practical Knowledge of the Soul", examines the grammar of the soul in a psychological and religious-theological aspect. Although this work came out three years after The Star of Redemption, and other works by Rosenstock-Huessy were mainly published after Rosenzweig's death, nevertheless, Rosenzweig was well aware of his friend's ideas and familiar with the manuscript of his book that had not yet been published. Most importantly, they discussed the concepts of speech thinking and grammar during their many conversations. Despite all the similarities of ideas, the philosophical grammar of Rosenzweig is strikingly different from the religiouspsychological grammar of Rosenstock-Huessy. The main thing is that it not only determines the fundamental role of language in reality but also penetrates into its meanings.

Rosenzweig not only sees in language an important element of the psychology of religion, as does Rosenstock-Hussy, but turns language into the cornerstone of the philosophical system. Therefore, speaking about the linguistic turn of the 20th century, it is impossible to ignore the grammatical conception of Rosenzweig. Although a lot of works have been devoted to the topic of speech thinking (Askani 2004; Casper 2004; Greenberg 1996; Meir 2005; Pollock 2019; Schmied-Kowarzik 2006, etc.), the connection of this thinking with the philosophy of Rosenzweig as a system is still not sufficiently researched. Hence follows the main task of this article-the study of the grammatical organon as the foundation of a new philosophical paradigm.

\section{Philosophical Foundations of Speech Thinking in Rosenzweig}

Since Plato and Aristotle, language has been considered as something secondary and not central to philosophy. In his "Hermeneutics", Aristotle proclaims that language is a way of denoting thought, and if thought corresponds to the object and does not depend on the thinker, then the language is conditional and the same objects are called differently in different languages (Aristotle, On Interpretation, 18a 4-9). True, in the philosophy of Aristotle, a certain role is given back to the language in his works devoted to the practical sciences-rhetoric and poetics-but all these fields are not considered as fundamental. Some glimpses of interest in language are observed in medieval philosophy and especially 
in mysticism, but in general, classical philosophy is completely focused on thinking, and the problem of language remains secondary until the 20th century. Rosenzweig sees the reason for the oblivion of language in philosophical idealism:

"the distrust toward language and its apparent "harmony" with thinking remains a lasting legacy of idealism, and it always pushes further on the descending slope of its "pure" logic, foreign to language, recessed behind man". (Rosenzweig 2005, p. 153)

Idealism in its foundation, starting with Parmenides, is built on the ontological method, the essence of which is the identity of thinking and being. Since language is not reducible to the relation between thinking and being, it eludes research. According to Rosenzweig, this evasion reaches its greatest scale in Hegel's philosophy, due to the total identification of being with thinking (Rosenzweig 2005, p. 52). Language, as it were, is entirely absorbed by the Hegelian system without turning into its subject. At the same time, the outstanding linguist contemporary of Hegel, Wilhelm Humboldt, realizes the importance of language, and his ideas are perceived and developed by Cohen's student Ernst Cassirer. However, Rosenzweig is not satisfied with these attempts (GS 1979, p. 540); he understands that the reappraisal of the place of language in philosophy requires a radical revision of its very foundations. One of the sources of such a revision for him was the ideas of philosophers who were trying to challenge the Kantian philosophy of reason, including those of Hamann, Herder and Schelling.

The very first researcher of Rosenzweig's philosophy, E.R. Freund, draws attention to the connection between Rosenzweig's speech thinking and the Schelling's narrative philosophy. In the book The Ages of the World (Die Weltalter), Schelling notes the connection of three tenses - past, present and future-with the ways of their verbal description:

"The past is known, the present is discerned, the future is intimated. The known is narrated, the discerned is presented, the intimated is prophesied". (Schelling 2000, p. XXXV)

The term narrative philosophy (erzählende philosophie), which Rosenzweig borrows from Schelling (Rosenzweig 1925, p. 436), characterizes the past, to which Schelling's book is devoted as a historical study, but according to Freund, Rosenzweig expands Schelling's thought and speaks of three forms of speech thinking-narration, dialogue and choral speech. (Freund 1979, p. 138). To better understand Rosenzweig's philosophy of language in relation to temporality, we must take a closer look at the general concept of The Star of Redemption.

The first part of the treatise is on the subject of the already existing world of the lasting past. As Rosenzweig explains, the subject of philosophy from Parmenides to Hegel was All in its universality and integrity (Rosenzweig 2005, p. 20). The All, the universal subject of philosophy, is seen as an element. Rosenzweig names three elements-the world, a man and God. Each of them can be viewed as an integral and closed universum. Rosenzweig cites mathematics as the main way to comprehend the elements. According to him, this is not about any particular part of mathematics but rather a mathematical method in general. The world of elements is realized in the images of the plastic world, the tragic hero and the mythological god (Rosenzweig 2005, p. 93). The elements are lacking openness precisely because they are complete and can be perceived by thought; because of their universality, they include everything, including each other, but include immanently, without interacting with each other as with something foreign. They exist in the continuous past, which means nothing new ever happens there; they are doomed to death, simply by virtue of their finitude.

Quite the opposite are the paths which are the subject of the second part of The Star of Redemption. Paths describe inter-element processes (Rosenzweig 2005, p. 274). They are transcendental to the elements themselves but perfectly real. Within the elements, path processes are observable, but not explainable (Rosenzweig 2005, p. 93) To describe the processes on the path, Rosenzweig uses Cohen's logic of the origin. The way to open 
up an element, i.e., its way out of isolation, is to appeal to its infinitely small origin in another element (Rosenzweig 2005, p. 28). God and man, who in their own elements represent everything, in the world element as such are not observable, but according to Rosenzweig, they are infinitesimal values—not-nothing, (Rosenzweig 2005, p. 37) —or the process of generation (Rosenzweig 2005, p. 58). Exactly these are described by the path. The three paths of the Rosenzweig's The Star of Redemption are Creation, Revelation and Redemption. If the elements are always described as continuous past, then the paths unfold in present time, although their traces remain in the past. In the third part of The Star of Redemption, elements and paths come into a dynamic unity in the image of the future, which is embodied in the concept of Gestalt (Rosenzweig 2005, p. 23).

If the awareness of the reality of the elements is thinking, which is fixed in its most perfect form by a logical-mathematical organon, then the processes on the paths have linguistic characters and are expressed by the grammatical organon. Language is a special reality which, on one hand, has an inter-element character, and on the other, it permeates the elements, becoming a kind of mediator between them (Schmied-Kowarzik 2006, p. 155).

Thus, language expresses the process of the relationship between God and the world, i.e., Creation, God and man, i.e., Revelation, and of the man and the world, i.e., Redemption. It is in the description of paths in the second part of his treatise that Rosenzweig unfolds his version of the philosophy of dialogue. According to Rosenzweig, language acts as a unifying mediator between elements. The main property of the language is the transcendent connection, or, using Cohen's terminology, the correlation with the elements.

Thus, language opens up the possibility for a man to absorb the world but not to merge with it. As already noted by Freund (Freund 1979, p. 10), thanks to language, a man turns out to be an unavoidable element of reality, i.e., linguistic philosophy out of necessity turns out to be human philosophy ${ }^{7}$. In Rosenzweig's philosophy, the man is not a part of the world but a separate element in a dynamic relationship with the world. Likewise, God does not merge either with the world or with the man. It is the immanent unity of God, the world and the man at the elemental level, according to Rosenzweig, that determines the mythological or pantheistic character of the old thought. (Bienenstock 2018 , p. 124). Schmied-Kowarzik reveals the role of language in human's acquisition of his special existence in detail and not only in an existential but also in a dialogical context:

"context of the meaning of his existence can be revealed to man only from the contemporaneity of his linguistic existence. The fact that the I, which we ourselves are, cannot existentially locate itself from within, but only addressed by the Other and responding to the Other, becomes for Rosenzweig-to a greater extent than for Cohen-the central idea of his foundation of existential and dialogical being-in-language". (Schmied-Kowarzik 2006, p. 151)

As a way of comprehending the past and realizing the present, language, according to Rosenzweig, is also becoming a way of appealing to the future through prayer (Rosenzweig 2005, p. 198). Thus, three organons are built around three tenses. Mathematics describes a perfect world, which has already been comprehended by thought and completed, which is the world of continuous past. Grammar describes the world that is unfolding right now in the present. Finally, liturgy is the appeal of a man to the world of the future (Rosenzweig 2005, p. 312). However, although these organons of three tenses are considered in three parts of Rosenzweig's book ${ }^{8}$, there is a deep connection between them in the overall composition of the book. Rosenzweig realizes that not only the paths but also the elements and the Gestalt of The Star of Redemption itself are permeated with language but in different ways. The element is seen as a pre-linguistic reality, which is defined as the silence of the pre-world (Rosenzweig 2005, pp. 312-13). Rosenzweig describes it as "language before language" (Rosenzweig 2005, p. 119). It is full of content, but is silent, because it is closed in itself. The ability of the elements to speak is built on their openness to each other. Therefore, the speech of the path comes directly from the silence of the elements. Finally, the third organon, the liturgy, also signifies silence (Rosenzweig 2005, pp. 199-200). It is 
a silent prayer that aims at the coincidence of divine and human will (Rosenzweig 2005, p. 292)

Thus, there is a direct connection between these three organons. Grammar reflects in its own way logical and mathematical foundations, and liturgy follows from grammar.

\section{Grammar and Logic. Root Words and Sentences of the Language}

Logical-linguistic parallelism is characteristic not only of Aristotle and medieval philosophy, but it is also accepted by Rosenzweig. Since the origin of language lies in the silent pre-world of thought, it is obvious to Rosenzweig that grammar in its own way repeats the basic operations of logic. At the same time, the grammatical organon is fundamentally different from the mathematical one. As Askani notes, mathematics describes the pre-world in the form of symbols, grammar describes a living language, that is, not the world, but a way of dealing with it. Asconi writes: dort die Sprache der Logik, hier die Sprache der Grammatik (SE 121), oder auch: dort das Denken, hier die Sprache, das sprachliche Denken:

"there is the language of logic, here is the language of grammar, or: there is thinking, here is language, linguistic thinking". (Askani 2004, p. 418)

To understand the nature of this linguistic thinking of Rosenzweig, we must compare it with the linguistic thinking of Rosenstock-Huessy, because both theories, as we mentioned, appeared in close contact with each other. As Brasser emphasizes, although Rosenzweig borrows from Rosenstock-Huessy the idea of the grammar of a human or the grammar of a soul (Rosenstock-Huessy 1988), there is a significant difference between Rosenzweig's theory and Rosenstock-Huessy's theory (Brasser 2004, pp. 181-83). Rosenstock-Huessy examines the grammar of a soul as a kind of psychology which, unlike ordinary empirical psychology, brings the soul out of its insulation and isolation with the help of language. Rosenzweig considers the separation and isolation of the soul not as a psychological phenomenon but as a fundamental state which can be theoretically described based on the analysis of logic. Thus, the linguistic dimension of a soul is already present at the stage of its isolation, and the task of language is not to build a dialogical dimension around the soul but to unveil the potential that is already present in it.

For Rosenzweig, the insulation of elements does not imply their doom, from which only language can extract them. This is an inner closure, and to overcome it, you do not need to leave the elements but have to open them up from inside. Language is immanent to elements, not to a superstructure of elements. As E. Meir writes (Meir 2005, p. 56) ${ }^{9}$ :

"The logic of the Old Thinking has been replaced by living language in the New

Thinking. Speech itself in not in Part I: only its elements, i.e., confirmation, negation and relation. Speech, i.e., grammar, is in Part II"

The root words and root sentences of grammar seem to grow out of the basic operations of logic.

Thus, for Rosenzweig there is a fundamental connection between grammatical root words and sentences with the basic operations of logic. As Rosenzweig states, "that language of logic is the prediction of a real language of grammar" (Rosenzweig 2005, p. 119). Still, a completely different work is carried out in language than in logic. The main property of logic, as well as of the generally silent pre-world of an element, is the integrity and completeness of the universum and its alienation from a particular person. The world, that was already thought, does not depend on one specific thinker who is thinking right now. Therefore, the "original words" (Urwort) of logic have an impersonal abstract character. Rosenzweig gives three such original words-“Yes", "No" and "And" (Rosenzweig 2005, pp. 35, 39, 41). These three original words formulate three logical operations-assertion, negation and conjunction. In the first part of The Star of Redemption, Rosenzweig examines in detail the application of these operations in relation to the singular and the general, but at the language level, according to Rosenzweig, root words and sentences (Stammwort, Stammsatz) take the place of original words. The first two books of the second part of the 
treatise are devoted to two root words and the third to a root sentence. Two root words "Good" and "I" correspond to logical operations of affirmation and negation and the root sentence to logical conjunction.

Unlike the formal statement "Yes," the root word "Good" is inseparable from the situation in which it is pronounced. Of course, "Good" (Gut, Hebrew טוב is also a form of a statement. When we agree with the opinion of the interlocutor, we say "Good!" At the same time, "good" is evaluation and recognition. In Plato and in most subsequent philosophical traditions, "good" ( $\alpha \gamma \alpha \theta$ óv) is regarded as the highest reality. The word "good" expresses the greatest value in the world, in a sense, the purpose of the existence of the world.

According to Rosenzweig, "good" is not an abstract idea of "goodness" as in Plato but a grammatical construction with a value, the root word of a language, which makes language a language. In this example, we see the difference between grammatical organon and mathematical organon, speech thinking from idealism ${ }^{10}$.

The word "good" expresses the greatest value in the world, in a sense, the purpose of the existence of the world, and at the same time, according to Rosenzweig, the value dimension is what makes language a language. In this context, Rosenzweig contrasts the personal dimension of the speaking soul in the second part of the book and the self-hood of the silent and closed soul of the first part ${ }^{11}$.

The second root word of the language is the first-person pronoun I. It is clear that where there is no I, there is no language. In the case of persons, Rosenzweig does not juxtapose different personal pronouns-I, Thou, He, It, We. All of them, from his point of view, are born from the I. The comparison of the first two logical original words "Yes" and "No" with the grammatical root words "Good" and "I" raises a number of questions. If "Good" is the obvious linguistic equivalent of "Yes," then what is the connection between "I" and "No". For Rosenzweig, this connection is undeniable, he writes: "I is always a No become audible" (Rosenzweig 2005, p. 187).

To understand the meaning of the negative content of the root word " $\mathrm{I}$ ", one needs to delve a little into Rosenzweig's criticism of ontology. In the first part of his treatise, he describes the universum and says that the inclusion of a singular person in it completely changes its nature (Rosenzweig 2005, pp. 17-18). The universum includes everything, but one unique person brings it out of integrity and closure and opens it up for another reality. Thus, a singular person, acting as an exception in relation to the universum, denies its integrity and makes it open. Such a denial inherent in the individual person translates the description of the world from thinking to the reality of language. (Pollock 2009, p. 78). In a language, "good" and "I" really appear as opposites. "Good" asserts integrity and perfection, while " $\mathrm{I}$ ", on the contrary, reveals exclusivity and uniqueness. At the same time, although these two root words oppose each other, they both carry a personal-valued meaning. The contrast of root words becomes the meaningful basis of the root sentence, where these words are connected to each other, acting as an analogue of the logical connective "AND":

"The And before language does not reveal itself in a root word, but in a genealogical sentence, hence a sentence made up of the two root words". (Rosenzweig 2005, p. 246)

The linguistic connection disclosed in the root sentence goes beyond the limits of individual words and describes an integral linguistic situation. Here, the language is already working in full force.

\section{Grammatical Structures}

Having formulated the philosophical foundations of the language, Rosenzweig gets the opportunity to build his grammatical organon. To determine the grammatical nature of the first root word of the language "Good", he compares it to the logical original word "Yes" in which, according to Rosenzweig, thinking finds a fulcrum for itself: 
"The original Yes was the word of the original position, and as such, in every word, was the silent partner, its role in the whole of the sentence". (Rosenzweig 2005, p. 39)

Rosenzweig defines the statement "Yes" as "an isolated predicative" (Das für sich genommene Prädikativum) (Rosenzweig 1921, p. 57). Thus, the task of grammar is to find at the language level a predicative corresponding to a logical statement. Rosenzweig formulates this challenge as follows: Welches bestimmte Wort wird nun in dieser Form des prädikativischen Adjektivs die Lautbarmachung des Urworts als Stammwort übernehmen? (Rosenzweig 1921, p. 162):

"But which specific word will assume, in this form of the predicate adjective, the transition to the audible universe from the original word, as long as it is a root word"? (Rosenzweig 2005, p. 138)

This word, as we know, turns out to be "Good", which contains not only a statement, but also an assessment. As Rosenzweig notes:

"The positive value judgment is nothing other than the primordial Yes become audible". (Rosenzweig 2005, p. 139)

Thus, we come to the conclusion that the basis of language, which distinguishes it from thinking, is the value dimension. According to Rosenzweig, this evaluative "good" is present in any event of language, the same way as a logical statement is present in any event of thought.

However, how can a grammar be built from the root word "Good"? According to Rosenzweig, the entire grammar cannot be constructed, but the part of it that describes the world, i.e., the grammar of creation can be built. To do so, we need to turn to the grammatical form of the first root word, which, as we said, is an isolated predicative. The predictability of the world is expressed in the fact that it has properties you can tell about it. However, as Rosenzweig emphasizes, the world itself, the world within itself is mute and speechless. Words do not arise from things but from relationships. Therefore, the first words are not names of objects, but pronouns. As Rosenzweig says:

"So the pronoun is much more pre-noun than pronoun; it does not designate the already known thing, but the thing as long as it is neither known nor named, as long as it is perceived only with its attributes". (Rosenzweig 2005, p. 139)

Pronouns describe the communicative situations from which language arises. Pronouns always express a personal attitude. It is they who become the pioneers of names and not vice versa. Then, if objects become such not by virtue of their existence, not in theory, not because we think of them, but because we are talking about them, according to the pronominal indication, the unique single objects acquire the same legitimacy as multiple common ones. This distinction, according to Rosenzweig, is made using the definite and indefinite articles (Rosenzweig 2005, pp. 139-40). Thus, acquiring multiplicity and uniqueness, "The singular thing, fixed by the definite article, can finally, therefore, be easily designated as object" (Rosenzweig 2005, p. 140). According to Rosenzweig, a thing becomes an object not because it exists by itself, such as in Aristotle, but because it can be talked about, i.e., the subject matter is born in the process of speech, not that previously given objects are described by speech. After becoming a subject matter, a thing acquires the ability to be subject and object in a sentence. It is in this capacity, as Rosenzweig notes, "It is only as object that it travels through the" cases (Rosenzweig 2005, p. 140). As Rosenzweig shows, different grammatical forms arise together and need each other:

"wherever we may wish to begin, they are themselves already entirely presupposed: the notion of noun, for instance, already presupposes the notions of case, number, and even person, and finally, the notions of subject and of object; but, in their turn, they are explained only by being based on the notion of the noun". (Rosenzweig 2005, p. 137) 
Having introduced a linguistic description of objects and their properties, Rosenzweig returns to his root word of the language "good", which, as we noted, is an expression of predictability. However, as Rosenzweig says, predictability not only presupposes descriptive properties but also movement in time:

"The overlapping takes place, in this case, in the form that governs the relationship between adjective and verb, that is, the relationship between thing and event". (Rosenzweig 2005, p. 141)

The common origin of an adjective and a verb from a predicative entails their internal linguistic connection with each other, and the influence of pronouns on generation of adjectives and verbs leads to the allocation of the third person of the past tense as a special verb form. Having discovered the connections of noun to space and verb to time, Rosenzweig uncovers the difference between them. As he notes, because of the qualitative difference of its respective "dimensions, which space does not show" (Rosenzweig 2005, p. 142), the differences in tenses are qualitatively different, and therefore, different tenses (past, future and present) are distinguished in the language. Nothing like this happens with space. Here, Rosenzweig has not yet figured out the meaning of this distinction, it is difficult to establish one at the stage of creation ${ }^{12}$. The language constructed in this way by Rosenzweig, as we noted, is not the whole language but the descriptive language of creation. It is based only on the first root word. However, this language is fundamentally different from what Aristotelian hermeneutics substantiating objects offers us. For Rosenzweig, all objects and events are an expression of relationships: They carry a value dimension and do not exist on their own. Describing Rosenzweig's deduction of grammar, Askani expresses both admiration and bewilderment:

"All forms, all linguistic instances do not arise in a uniform, moderately calm form, but rather in astounding, overwhelming haste. $<\ldots>$ Human language that speaks of reality. Together with grammar, an entire world arises, namely the world of creation". (Askani 2004, p. 420)

There are two points to note here. Firstly, the haste in Rosenzweig is due to the fact of the one-time birth of a language. The description of this birth is a process, and the birth itself is a singular event. Secondly, the language of creation, of which Askani speaks, is not the whole language. It describes reality only on one path, and the completeness of the language is realized in the combination of all three paths. For this last reason, we should move on and take into consideration the second root word "I".

It is important to note that the "I" appears for the first time not in the second book of the second part of The Star of Redemption but in the very first pages (Rosenzweig 2005, p. 9). Even in the section devoted to the language of creation, Rosenzweig dwells in detail on the criticism of the concept of " $\mathrm{I}$ " as an expression of the transcendental subject in the philosophy of idealism (Rosenzweig 2005, p. 149). What is the specificity of the "I" as a root word of the language?

Rosenzweig answers this question in the section "Dialogue Form." "I" becomes the real root word of the language only in dialogue, in which it discovers its uniqueness and singularity. According to Rosenzweig, a man as a part of the world is not unique: He is one of many creatures, and people themselves are a multitude. The uniqueness of a man is manifested in his relationship with God. Like God, a man is completely isolated from the world and is a separate element claiming integrity and universality. Thus, the relationship between God and a man, the path of Revelation, is not a relationship within the world; it is singled out and has its own separate structure. However, this kind of relationship also turns out to be a reality between people because each man is unique and represents a whole world. Initially, the concept of "I" that Rosenzweig extracts from the dialogue of God with himself is "let us make a man" (Genesis 1:26), but subsequently, this dialogue extends to the relationship between God and a man and the relationship between people (Rosenzweig 2005, p. 167). Thus, the root word "I" becomes the basis of the dialogical form in which questions, answers, command, calling, listening, etc., emerge. 
The expansion of grammar when referring to the language of revelation is accompanied in Rosenzweig by the emergence of the new prospects. The objects of the language are now the objects that could not have been discussed before-command, love, commandment, man, woman, present, future. In the center of the language suddenly appears a system of personal pronouns, which Rosenzweig is silent about when talking about the language of creation. Of course, we are aware that language has mood, gender, person, time. However, it is only now that they have become part of the grammatical organon, only now that they are brought out in the process of unfolding the Gestalt of The Star of Redemption.

Surely, the discussion of dialogical grammar and Rosenzweig's logic requires a separate extensive discussion. Now we only have to stress that, according to Rosenzweig, the conversation about language does not end on the paths of Creation and Revelation and requires a transition to the main theme of the book-the path of Redemption. After all, the language has three roots- "Good", "I" and "root sentence".

The root sentence should make the grammatical organon perfect. It connects the root word "Good", which signifies the created world, and the root word "I", which expresses the personality revealed in the dialogue. Their connection, according to Rosenzweig's plan, should describe the unity of the "We" in the world, which is embodied in a choral form (Rosenzweig 2005, pp. 248-54). It is clear that no words, even root words, are sufficient for the implementation of the language, which becomes itself only in a sentence. It means that in Rosenzweig, the language can be fully implemented only as a result of the connection of all three paths which occurs in Gestalt. Therefore, the third book of the second part should contain the main key to the grammatical organon, but we do not find any grammatical theory in this book. Indeed, grammar, as Rosenzweig understands it, significantly expands beyond the known linguistic concepts ${ }^{13}$. There is no exploration of known grammatical structures in the third book of the second Part, but we find there an intense completion of literary theory. In this Book, individual grammatical forms are not considered at the level of the root sentence but rather literature in all its forms, the core of which is poetry:

"It can only be the community of the song, and this community not as a fait accompli, not as an indicative, but as a fact established at the moment"14. (Rosenzweig 2005, p. 249)

It is important to point out that the third part of the grammatical organon leads us to a broader understanding of language phenomena, which includes not only literature but also art in its entirety. Moreover, it turns out that the religious practice, to which the third part of The Star of Redemption is largely devoted, is in a sense a language. An illustration of this thought is Rosenzweig's formulation from the "New Thinking":

"And now this great world Poem is retold in three tenses. However, it is really narrated in the first book alone, the book of the past. In the present, the narration gives way to immediate exchange of speech, because what is present, whether human beings or God, cannot be spoken of in the third person; they can only by listened to and addressed. And in the book of the future, the language of the chorus governs, for the future seizes even the individual only where and when it can say We." (Rosenzweig 2000, p. 125)

\section{Language and Religion}

As you know, Rosenzweig did not like the word religion. He said that "God created precisely not religion, but rather the world" (Rosenzweig 2000, p. 129), spoke sarcastically of theology (Rosenzweig 2005, p. 103) and was very indignant when The Star of Redemption was regarded as a religious book (Rosenzweig 2000, pp. 109-10). All this does not question the fact that religious ideas were a fundamental part of his philosophical system. Moreover, without turning to God, according to Rosenzweig, we cannot claim to understand such a specific phenomenon as language. The explanation is as follows. In order for the language to speak, we must get out of the closure of the completed world in which a soul (self) 
exists at the level of the element, and such a way out involves the possibility of turning to God and man. The two most important paths of The Star of Redemption-Creation and Revelation-describe dynamics of the relationships between the world and the man with God. Therefore, without God, there is no language. Understanding becomes a bit more complicated when the third path is considered. Redemption, as the dynamic of the inter-element relationship between the man and the world, does not necessarily imply a conversation about God, but in Rosenzweig's particular system, Redemption unfolds in the Gestalt of the star in the process of the relationship between Creation and Revelation. Therefore, it is obvious that without God, Redemption is also unthinkable. In other words, all three paths, and therefore language in all its entirety, have a religious dimension. Let us consider this dimension in more detail at all three stages of the Gestalt unfolding.

What is the role of language in the context of the first path? As Askani notes, when faced with language, the pre-world turns into creation (Askani 2004, p. 413). It means that the whole world, thanks to language, is perceived as a living reality filled with Divine and human dimensions. However, this does not indicate a direct connection between language and religion. Language is something much more ancient and primordial than any particular form of religion. However, since "God created precisely not religion, but rather the world", the manifestation of God in the world, which according to Rosenzweig is implemented in language, extends far beyond the limits of religion as such. Rosenzweig states:

"For language is truly the wedding gift of the Creator to humanity; and yet at the same time the mutual possession of the children of men, in which each has his particular share and finally the seal of humanity in man". (Rosenzweig 2005, p. 120)

What is this wedding gift? In accordance with ancient Germanic tradition, the groom gives the bride a morning gift after the first wedding night (in the original morning gift Morgengabe) (DRW 1996, Bd. 9. p. 92ff). In other words, language, being a manifestation of the relationship between God and man, is at the same time the embodiment of human freedom and autonomy. What does "the seal of humanity in man" mean? In the context of the philosophical tradition that comes from Kant, Hegel and Cohen, Rosenzweig understands that each individual person is a person to the extent that the idea of humanity is realized in him. Hegel says that it happens in history, Cohen attributes it to the messianic idea and Rosenzweig discovers that connection of a person and humanity realizes itself through language.

It is certainly no coincidence that Rosenzweig named the second book of the second part, the central section of The Star of Redemption, "Revelation or the ever renewed birth of the soul". As we noted, Rosenzweig agrees with Rosenstock-Huessy's concept of the role of language in opening the soul and bringing it out of closure (Freund 1979, p. 152; Brasser 2004, pp. 196-200; Bienenstock 2018, p. 135, etc.). However, for Rosenzweig, language is an inherent attribute of the soul which is revealed on the path of Revelation. This allows Rosenzweig not only to consider within the framework of his concept a variety of religious and philosophical traditions but even to regard biblical revelation as the phenomenon of language revelation.

Each of the three books of the second part of The Star of Redemption includes a commentary on one of the fragments of biblical text. All these commentaries are not an appendices to the text but are rather a part of the harmonious development of Rosenzweig's grammatical philosophy. As Askani notes, Rosenzweig supplements his grammatical logic of the language with a grammatical analysis of the biblical text (Askani 2004, p. 415). This means that the biblical text itself becomes part of Rosenzweig's philosophy. On the other hand, we can say the opposite: In his philosophy, Rosenzweig creates a new interpretation of the biblical text. This also applies to the description of the birth of language in the chapters devoted to the creation of the world and to the commentary on the Song of Songs, which, as Bienenstock (Bienenstock 2018, p. 64) notes, is a meditation on the language of love, as well as to the description of the process of world history in the Rosenzweig'c commentary 
on psalm 115. Finally, the cosmological and historiosophic doctrine formulated in all three parts of The Star of Redemption describes the world on a truly biblical scale.

As Askani notes, Rosenzweig admits in his letter to Richard Koch dated 2 September 1928 that he originally intended to write a commentary on the Bible but abandoned this plan and wrote The Star of Redemption (Askani 2004, p. 411; GS 1979, p. 1196). Nevertheless, Rosenzweig carried out his preliminary plan. Perhaps he did even more-he renewed biblical content in modern speech. According to Askani, the biblical content of The Star of Redemption is not limited to those chapters in which Rosenzweig works with the biblical text but is extended to the entire book. Thinking ceases to originate only from itself and starts to originate from the biblical text (Askani 2004, p. 413). In other words, the language realized through the biblical text leads to the correction of the self-closed thinking.

As Casper notes, the task that Rosenzweig undertakes in The Star of Redemption is in many ways similar to the task of translating the Torah into modern language, only unlike the translation into German, which Rosenzweig subsequently carried out with Buber, this one is a translation into the language of modern thought. This mission is an important element of the Jewish tradition. Rosenzweig, in his concept of translation and repetition, follows the Talmudic practice of the continuous reading of the Torah afresh. Thus, a new oral implementation is formed based on the written text (Casper 2004, pp. 215-16).

\section{The Significance of Rosenzweig's Grammatical Organon in Philosophy}

Summing up our analysis, we can say that Rosenzweig's grammatical organon is not only a new attempt to comprehend language but a new philosophy that determines the central place of the language in human existence. It does not mean that the grammar proposed by Rosenzweig can claim to be a detailed description of the language, nor does the grammatical organon described in the three books of the second part of The Star of Redemption claim to formulate a specific grammatical description.

It seems to us that the meaning of Rosenzweig's grammatical organon is not limited to the presentation of a specific grammatical theory and even to the formulation of a new philosophy of language. Rosenzweig quite clearly presents his ideas as a turning point in thinking. He speaks of a "new thinking" that should replace "philosophy from Parmenides to Hegel." The grammatical organon is central to the implementation of this ambitious plan.

To clarify the last statement, we must dwell a little on the importance of the method in classical philosophy. After all, the word "organon" itself denotes an instrument, in this case-an instrument of cognition, comprehension, etc. If the logical-mathematical organon is really an instrument of cognition of the already existing world, then the linguistic grammatical organon allows us to join reality, be an active part of it, change the world, influence the future. Of course, in the classical "old" thinking, a person is understood as an active being, changing the world and discovering something new. However, there is no direct connection between his knowledge and actions. Rosenzweig's philosophy tries to bridge this chasm. In the formation of dynamic relations between the world, God and man, per Rosenzweig, language and, accordingly, the "grammatical organon" play a central role. Man as a not only thinking and acting but also a speaking being radically changes his place in relation to the world and God.

Turning to Rosenzweig's plan for the renewal of thinking a hundred years later, we cannot help but be surprised at his boldness and radicalism. The past century has shown that the very survival of a person depends on his ability to think differently. This, according to Rosenzweig, first of all means handling the language differently. We do not suggest that the philosophical grammar as developed by Rosenzweig must necessarily be accepted. Rather, it means that, based on his ideas, we should rethink the language and build a new linguistic philosophy.

Funding: This research received no external funding.

Institutional Review Board Statement: The study was conducted according to the guidelines of the Declaration of Helsinki. 
Informed Consent Statement: Informed consent was obtained from all subjects involved.

Data Availability Statement: Not applicable.

Acknowledgments: I would like to express my gratitude to A. Rybalov and M. Eskina for their help in preparing the article.

Conflicts of Interest: The author declares no conflict of interest.

\section{Notes}

1 In his book, Rorty (1967) speaks primarily of analytical philosophy, but the language turn took place in neo-Kantianism (Cassirer), and in phenomenology (Heidegger), and in psychoanalysis (Lacan), but most of all in the philosophy of dialogue (Ebner, Bakhtin, Rosenzweig, Rosenstock-Huessy, etc.

2 The significance of Rosenzweig's grammatical doctrine in the language turn of the 20th century is noted by (Casper 2004, p. 216; Dober 1990, pp. 62-65; Meir 2005, p. 181).

3 See (Pollock 2019) for an overview of Rosenzweig's speech thinking.

4 (Rosenzweig 2005, p. 20). In all cases when it is not required to refer to the German original of "The Star of Redemption" we provide links to its English translation.

5 After all, it is no coincidence that the epigraph to the 2nd edition of Critique of Pure Reason is F. Bacon's aphorism/(Kant 1998, p. 91).

6 For the relation of Rosenzweig's concept of language to Hamann's, see (Horwitz 1997).

7 Freund's conclusion that Rosenzweig's philosophy is a form of existentialism is not justified. In 1933, when Freund's book was written, existentialism had just emerged. In addition, Rosenzweig's concept really has a lot in common with existentialism, for example, reliance on Kierkegaard.

8 Rosenzweig himself considered them independent. (Rosenzweig 2000, p. 112).

9 Reference to Gritli's letter 10/1/1918. See (Briefe 2002, p. 156).

10 Although Rosenzweig opposes idealism, he does not reject it, but tries to rethink and offer his alternative.

11 In a letter to Gritli dated 1 October 1918, See (Briefe 2002, p. 156) Rosenzweig describes in detail the fundamental difference between self (Selbst) and personality (I). See (Meir 2005, pp. 56-57).

12 The problem of time and its arbitrariness is discussed in (Bienenstock 2018, pp. 139-40).

13 It reveals an amazing connection with the ideas of another great philosopher of dialogue of the early 20th century M. M. Bakhtin. In his theory of verbal creativity Bakhtin starts from the point that Rosenzweig reached in his reflections (See Dvorkin 2021).

14 It should be noted that the song, as the embodiment of the idea of redemption and thereby the unity of the human and divine world, is one of the central concepts of Judaism, permeating the Jewish tradition from biblical times to the present. It's appropriate to mention a Midrash here in which king Hezekiah, the king of Judah, after Solomon second in his greatness, did not become the messiah, precisely because he did not sing a song. Midrash Shir ha-Shirim, 4, 20.

\section{References}

Askani, Hans-Christoph. 2004. Schöpfung der Welt und Grammatik der Sprache. Zum Verhältnis von philosophischem Gedanken und biblischem Text im Stern der Erlösung. In Rosenzweig als Leser: Kontextuelle Kommentare zum "Stern der Erlosung". Edited by Martin Brasser. Tübingen: Max Niemeyer Verlag, pp. 411-28.

Berlin, Isaiah. 1993. The Magus of the North: J. G. Hamann and the Origins of Modern Irrationalism. London: J. Murray.

Bienenstock, Myriam. 2018. Cohen und Rosenzweig. Ihre Auseinandersetzung mit dem deutschen Idealismus. Freiburg and München: Verlag Karl Alber.

Brasser, Martin. 2004. Rosenstock und Rosenzweig über Sprache. Die Angewandte Seelenkunde im Stern der Erlösung. In Rosenzweig als Leser: Kontextuelle Kommentare zum "Stern der Erlosung" Tubingen. Edited by Max Niemeyer. Tübingen: Verlag, pp. $173-207$.

Briefe. 2002. Die "Gritli"—Briefe. Briefe an Margrit Rosenstock-Huessy. Edited by Inken Rühle and Reinhold Mayer. Tübingen: Bilam Verlag.

Casper, Bernhard. 2004. Franz Rosenzweig. Die Herausforderung zu einer neuen Zukunft. In Rosenzweig als Leser: Kontextuelle Kommentare zum "Stern der Erlosung" Tubingen. Edited by Max Niemeyer. Tübingen: Verlag, pp. 209-22.

Dober, Martin. 1990. Die Zeit ernst nehmen: Studien zu Franz Rosenzweigs "Der Stern der Erlösung" (Epistmata [sic]. Würzburger Wissenschaftliche Schriften. Reihe Philosophie. Band LXXXIV). Würzburg: Könighausen und Neumann.

DRW. 1996. Deutsches Rechtswörterbuch. Bd. 9. Heidelberg: Heidelberger Akademie der Wissenschaften.

Dvorkin, Ilya. 2021. Bakhtin and Cohen: The First Stages in Building the Philosophical System. RUDN Journal of Philosophy 25: 436-56. [CrossRef]

Freund, Else-Rahel. 1979. Franz Rosenzweig's Philosophy of Existence. Berlin/Heidelberg: Springer-Science + Business Media, B.V.

Greenberg, Yudit Kornberg. 1996. Better than Wine: Love, Poetry, and Prayer in the Thought of Franz Rosenzweig. Atlanta, Ga.: Scholars Press. GS. 1979. Franz Rosenzweig, Der Mensch und sein Werk. Gesammelte Schriften I, 1. Hague: Martinus Nijhoff. 
Horwitz, R. 1997. Hamann and Rosenzweig on Language: The Revival of Myth. In Daat: A Journal of Jewish Philosophy E Kabbalah. N38 (1997). Ramat Gan: Bar Ilan University Press, pp. V-XXVIII.

Kant, Immanuel. 1998. Critique of Pure Reason. Translated and Edited by P. Guyer and A. W. Wood. Cambridge: Cambridge University Press.

Meir, Ephraim. 2005. Letters of Love: Franz Rosenzweig's Spiritual Biography and Oeuvre in Light of the Gritli Letters. New York: Lang.

Pollock, Benjamin. 2009. Franz Rosenzweig and the Systematic Task of Philosophy. New York: Cambridge University Press.

Pollock, Benjamin. 2019. Franz Rosenzweig.-The Stanford Encyclopedia of Philosophy (Spring 2019 Edition). Edited by Edward N. Zalta. Available online: https://plato.stanford.edu/archives/spr2019/entries/rosenzweig/ (accessed on 19 October 2021).

Rorty, Richard. 1967. The Linguistic Turn. Recent Essays in Philosophical Method. Edited by Richard Rorty. Chicago and London: University of Chicago Press.

Rosenstock-Huessy, Eugen. 1988. Practical Knowledge of the Soul. Translated by. Mark Huessy and Freya von Moltke. Norwich: Argo Books. Originally published as 1924. Angewandte Seelenkunde. Darmstadt: Roetherverlag.

Rosenzweig, Franz. 1921. Der Stern der Erlösung. Reprint 1996. Mit einer Einführung von R. Mayer und einer Gedenkrede von G. Scholem. Frankfurt am Main: Suhrkamp.

Rosenzweig, Franz. 1925. Das neue Denken. Eine nachträgliche Bemerkung zum, Stern der Erlösung. Der Morgen: Monatsschrift der Juden in Deutschland, vol. 4, pp. 426-51.

Rosenzweig, Franz. 2000. The New Thinking.-Philosophical and Theological Writings. Translated and Edited by Paul W. Franks and Michael L. Morgan. Indianapolis: Hackett Publishing Company, pp. 109-39.

Rosenzweig, Franz. 2005. The Star of Redemption. Translated by B. E. Galli. Madison: University of Wisconsin Press.

Schelling, Friedrich Wilhelm. 2000. The Ages of the World. Fragment from the Handwritten Remains, 3rd ed. Albany: State University of New York Press.

Schmied-Kowarzik, Wolfdietrich. 2006. Rosenzweig im Gespräch mit Ehrenberg, Cohen und Buber. München: Verlag Karl Alber Freiburg. 